\title{
Public administration of the interaction between government and business: European experience for Ukraine
}

\section{Kvitka S. A., Dnipropetrovsk regional institute of public administration of National academy for public administration under the President of Ukraine}

The role that business plays in the life of modern Ukrainian society could not but attract close attention from the scientific community and, above all, representatives of the sciences of public administration. This topic has become especially relevant with the intensification of Ukraine's participation in globalization processes and the need to strengthen the role of the state in the socio-economic life of society.

The most widespread European concepts of the state governance of power and business interaction have been studied in the article, in particular corporatism, pluralism, instrumentalism, etc. An analysis of the peculiarities of the interaction between the power and business in Ukraine has been conducted on their basis. Various theoretical and methodological approaches to the study of business as a political actor have been considered. Groups of interests and pressure groups are the types of protectionist groups that influence the actions of modern governments both in Europe and in Ukraine.

The society consists of a large number of such groups of interests and pressure groups, which represent all significant interests of the population and compete for the influence over the state power. This competition takes place within the framework of the cross-sectoral partnership, that is, the consensus reached on the basic foundations of the economic and political system and the permissible level of conflict. In developed democracies, competition between groups and between sectors of society ensures a situation in which none of the groups dominates and the balance of interests is kept. This balance plays a crucial role for the stability of the existing social system.

The author has come to the conclusion that among the concepts of the interaction of power and business, which had been studied in the article, the liberal corporatism is the most acceptable for Ukrainian realities. Understanding the state as a separate corporation, which has its own, different from the business structures and civil society's interests, but which builds partnership relations with them, provides opportunities for a more detailed analysis of the organizational forms of the interaction between the authorities and business, the peculiarities of the state administration in this sphere, and in addition takes into account the tendencies of globalization, which impose their restrictions on this interaction.

Keywords: Ukraine; business; power; state; groups of interests; pressure groups; corporatism; pluralism

\section{Державне управління взаємодією влади та бізнесу: європейський досвід для України}

Квітка С. А., Дніпропетровський регіональний інститут державного управління Національної академії державного управління при Президентові України

Роль, яку бізнес відіграє у житті сучасного українського суспільства, не могла не привернути до нього пильної уваги з боку наукового співтовариства i, перш за все, представників наук із державного управління. Ця тема набула особливої актуальності з активізацією участі України в глобалізаційних процесах та необхідністю посилення ролі держави у соціально-економічному житті суспільства.

У статті розглянуто найбільш поширені в Європі концепції державного управління взаємодією влади та бізнесу, зокрема корпоратизм, плюралізм, інструменталізм тощо. На їх основі проведено аналіз особливостей взаємодії влади та бізнесу в Україні. Розглядаються різні теоретико-методологічні підходи до вивчення бізнесу як політичного актора. Групи інтересів та групи тиску є різновидами протекціоністських груп, які впливають на дії сучасної влади, як в Свропі, так і в Україні. Суспільство складається з великої кількості таких груп інтересів і груп тиску, які представляють всі значні інтереси населення і конкурують між собою за вплив на державну владу. Ця конкуренція проходить у рамках міжсекторального партнерства, тобто досягнутого консенсусу з приводу базових основ економічної і політичної системи та допустимого рівня конфлікту. У країнах розвиненої демократії конкуренція між 
групами та секторами суспільства забезпечує такий стан, при якому жодна з груп не домінує, і зберігається баланс інтересів. Цей баланс відіграє вирішальну роль для стабільності існуючої соціальної системи.

Автор робить висновок, що з розглянутих у статті концепцій, які аналізують взаємодію влади та бізнесу, найбільш прийнятним для українських реалій $є$ ліберальний корпоратизм. Розгляд держави як окремої корпорації, яка має свої відмінні від бізнес-структур та громадянського суспільства інтереси i при цьому будує з ними партнерські відносини, надає можливості більш детально аналізувати організаційні форми взаємодії влади та бізнесу, особливості державного управління у цій сфері, до того ж враховуючи тенденції глобалізації, що накладають свої обмеження на цю взаємодію.

Ключові слова: Україна; бізнес; влада; держава; групи інтересів; групи тиску; корпоратизм; плюралізм

\section{Государственное управление взаимодействием власти и бизнеса: европейский опыт для Украины}

\section{Квитка С. А., Днепропетровский региональный институт государственного управления Наци- ональной академии государственного управления при Президенте Украины}

Роль, которую бизнес играет в жизни современного украинского общества, не могла не привлечь к нему пристального внимания со стороны научного сообщества и, прежде всего, представителей наук по государственному управлению. Эта тема приобрела особую актуальность с активизацией участия Украины в глобализационных процессах и необходимостью усиления роли государства в социальноэкономической жизни общества.

В статье рассмотрены наиболее распространенные в Европе концепции государственного управления взаимодействием власти и бизнеса, в частности корпоратизм, плюрализм, инструментализм и тому подобное. На их основе проведен анализ особенностей взаимодействия власти и бизнеса в Украине. Рассматриваются различные теоретико-методологические подходы к изучению бизнеса как политического актора. Группы интересов и группы давления являются разновидностями протекционистских групп, которые влияют на действия современной власти, как в Европе, так и в Украине. Общество состоит из большого количества таких групп интересов и групп давления, которые представляют все значительные интересы населения и конкурируют между собой за влияние на государственную власть. Эта конкуренция проходит в рамках межсекторального партнерства, то есть достигнутого консенсуса по поводу базовых основ экономической и политической системы и допустимого уровня конфликта. В странах развитой демократии конкуренция между группами и секторами общества обеспечивает такое положение, при котором ни одна из групп не доминирует и сохраняется баланс интересов. Этот баланс играет решающую роль для стабильности существующей социальной системы.

Автор делает вывод, что из рассмотренных в статье концепций, анализирующих взаимодействие власти и бизнеса, наиболее приемлемым для украинских реалий является либеральный корпоратизм. Рассмотрение государства как отдельной компании, которая имеет свои отличительные от бизнес-структур и гражданского общества интересы и при этом строит с ними партнерские отношения, предоставляет возможности более детально анализировать организационные формы взаимодействия власти и бизнеса, особенности государственного управления в этой сфере, к тому же учитывая тенденции глобализации, накладывают свои ограничения на это взаимодействие.

Ключевые слова: Украина; бизнес; власть; государство; группы интересов; группы давления; корпоратизм; плюрализм

\section{Problem statement.}

7 he role played by business in the life of modern Ukrainian society could not but attract the attention of the scientific community and, above all, the representatives of the science of public administration. This topic has become especially relevant with the intensification of Ukraine's participation in the globalization processes and the strengthening of the role of the state in the socio-economic life of society. Uncontrolled business development began to slow down further progress of the country and to contradict global trends in this sphere. Therefore, in our opinion, the study of the phenomenon of cooperation and partnership between government and business in modern conditions is an actual problem, especially since the «western» 
science has already accumulated a considerable theoretical basis on this subject. As the in-depth analysis of the state-business interaction in Ukraine is just developing, the theoretical and methodological approaches to this issue that have already been developed in the world can become the basis for further studies of the Ukrainian peculiarities of this phenomenon.

\section{Analysis of researches and publications.}

Nowadays there is a sufficiently wide range of scientific publications, which cover various managerial aspects of the state-business interaction. The main theoretical basis is formed by works of such foreign authors as Wilson G., Buchanan J. S., Lipset S. M., Sen K.-R., Torres D. C., Aslund A., F. A. von Hayek , Frank R., Etzioni A., Eggtersson T., Adams R., Jordan G., Adams R., Polanyi K., Johnston M. and others. The specifics of the cross-sectoral social partnership, the social responsibility of the business, its political interests and other theoretical and methodological aspects of the study of the role of business as a political actor have been revealed in the studies of Ukrainian and Russian scientists L. Abalkin, V. Velekova, S. Peregudova, A. Gelman, S. Karaganova, G. Kleiner, V. Supyan, V. Makarova, A. Shokhin, V. Radayev, F. Shamhalov and others.

The aim of the study is to identify the main theoretical and methodological approaches to the study of business, which were formed in the scientific concepts of Europe and the United States in the twentieth century, and are an essential basis for the continuation of researches of this sphere in Ukraine. Despite the diversity of views on this issue, there is a unified opinion among scholars that the public administration in the socio-economic sphere of the modern world is impossible without taking into account the activities and influence of business structures being political actors.

\section{Presentation of the main material.}

Among many scientific approaches to understanding business as a socio-political actor, the author has studied those that are the most recognized today and are used in the analysis and researches of the interaction between government and business. The first one is the concept of «industrial relations», which considers the system of power-business to be an evolving matrix of coordinated interactions between the state, employers and trade unions at the level of firms and industries. The state and business together with trade unions take part in the development and 50 application of rules aimed at preserving peace, regulating disputes and generating predictability.

This approach is based on the fact that there is a limited set of activities which are constantly needed to coordinate work in industrial societies. As a result they are becoming more or less similar in all societies that are at a similar stage of development. It should be noted that the amount of such countries is decreasing and Ukraine is in the process of transition from «industrial» to «post-industrial» stage of development. The concept of «industrial relations» understands the issue of interests, power, control and conflict, which underlie labor relations as the main pillar of sociopolitical and socio-economic relations. In such case the question of mechanisms and technologies of their solution goes to the background. This explains the shift from the traditional concentration of attention solely on the institutional aspects and the desire to study a wider range of social phenomena that affect the relations of workers, employers and authorities. Studies of «industrial relations» are based on a rich database. However, this approach somewhat simplifies the situation considering actors in a limited space of their place of work to be a system that is more or less independent. The presence and valence of actors and processes that play the main role in preserving the system of public administration is lost.

The «instrumentalist» concept of businessgovernment relations is also worth attention. Proponents of this approach argue that in the modern society the state is an instrument of the economically dominant class of capitalists. According to the ideas of the instrumentalists in conditions of democracy the class of capitalists almost completely subordinates the state apparatus to its will and dominates politically through it over society and over subordinated classes, the working class first of all. Instrumentalists point out the most important means and tools by which capitalists turn their economic power into political power, submit the state to their desires. Among them are as follows: the direct involvement of business into the work of the state apparatus and into closely-connected with the state groups of policy development; funding of political parties and candidates; lobbying activities of individual capitals, industries and business unions; manipulating the political consciousness of voters with the help of media, controlled by the capital.

This concept of the relationship between the «ruling class» and the state, ascending to K. Marx and F. Engels, dominated entirely in the Soviet political science $[2 ; 5]$. One of the most important 
shortcomings of the «instrumentalist» concept is that it represents the relationship between the «ruling class» and the state in bourgeois society as a purely subjective relationship and reduces the relations of the social class and state to the interpersonal relations of individuals. By instrumentalists, the capitalists in various ways affect officials deliberately (lobbying, financing, etc.) and subject the officials to their will, to their goals in these subjective, interpersonal relations. Focusing on subjective, interpersonal relations between the capitalists and the officials, the goal-setting forms of the capitalists influencing the officials, the instrumentalists do not see that these relations and forms of influence play a minor role in the mechanism of class domination. Nicos Poulantzas said rightly so: «Relations between the bourgeois class and the state are objective relations. This means that if the function of the state in a certain social formation and the interests of the dominant in this formation coincide, then this follows from the system itself: the direct involvement of the members of the ruling class in the state apparatus is not a cause, but a consequence, and moreover, an opportunity, and, moreover, a random opportunity of this objective coincidence» [7, p.245]. Indeed, the very placement of the state in the structure of bourgeois social function puts it in an objective dependence on the economy, on the process of capitalist production and accumulation. Due to this dependence, due to the structural coercion, the state is interested and is forced to pursue a policy that promotes capital reproduction, which is in the interest of big business. Due to the objective, structural dependence of the state on the economy, on the process of production and accumulation, businessmen who organize and direct this process is an investor and such businessman can influence state indirectly and the role of this «investor pressure» in the mechanism of class dominance of capital is much more important than the role of intentional forms of influence, which are accentuated by «instrumentalists».

For modern Western society a unique institutional distribution between the «economic» and the «political» is the most characteristic. The state takes a form of a relatively isolated from the economy, so called, «built-in» apparatus of the public authority. It is excluded from the productive core of the economy, where the leading role is played by the private capital. It can be said that in the capitalist system the political power is disconnected from the organization of production in accordance to its own political criteria. But, being generally excluded from the organization of the process of production and accumulation, the state and, above all, the political elite depend objectively on the capitalist economy.

C. Offe and F. Rong noted: «Since the state depends on the accumulation process, which it can't organize, each possessor of state power is interested mainly in maintaining the conditions, which are the most favorable for the accumulation. This interest does not come from the union of a certain government with a certain class, which is also interested in the accumulation, it does not come from any political power of the class of capitalists, which exerts pressure upon the rulers of the state power in order to follow their class interest. Most likely, it comes from state's own institutional interest, which is based on the fact that the state has no ability to control the flow of those resources, which are required for the use of the state power. Agents of accumulation are not interested in the «use» of the state power, but the state should be interested in ensuring and guaranteeing a healthy accumulation process from which it depends in order to keep its own authority «[6, p.250].

The role of business as an important political actor can also be analyzed in terms of more general methodological approaches, characteristic of modern science of public administration. In particular, this concerns a pluralistic approach in which business is seen as a group of interests or pressure groups. At the same time, not giving preference to any of many classifications of these groups, it is important to outline the role they play in the political life of modern society.

A. Bentley defines «interest groups» as «... associations of citizens that are considered not as an abstract physical entity, but as a mass activity ...». Their interaction with the institutes of the state is of great importance, as it is in the socio-economic sphere, the coordination of the positions of interest groups and the state is the determining factor of state policy. There is a clearly defined political component in activities of these groups, as state institutions are the index of the balance of interests of different groups that permeate society from the bottom up. As soon as the society develops, changes take place and the structure of the balance of interests changes. This inevitably leads to corresponding modifications in the legislation and in the ratio of powers between different branches of government. In this case, the main task is not to impose decisions on individual groups, but to be able to bring to the consensus the largest and the most powerful among them $[8, \mathrm{p} .20]$. 
D. Truman, who defined the political process, first of all, as a process of group competition in the struggle for power over resource allocation, classified business associations as «political groups of interests» as they strive to achieve the goal through government institutions, that is, make a political pressure on them. Their significance he saw in the fact that the interest groups in general not only serve to the stabilization of the society, but also contribute to raising the level of political participation of citizens in the management of the state. D. Truman believed that while society diversifies, it creates new interest groups automatically. They violate the existing balance of power and stimulate the emergence of «counter-groups» for its restoration [9].

Russian scientist V. Achkasov within the framework of a pluralistic concept calls groups of interests to be the institutional structures of various types (entrepreneurial, trade union, religious, ethnic, cultural, etc.) which try to influence the political power without applying for it. They act as intermediaries in securing the specific interests of their members $[1$, c. 168$]$.

In the modern Western political science the term «pressure group» is the most widely used in relation to business associations. Although some experts see no significant difference between such concepts as «interest groups» and «pressure groups», the term «pressure group» is often equated with «protectionist» groups. Defending primarily material interests of their members they can apply sanctions, thus fulfill the direct pressure to achieve their goals. However, we can agree with the point of view that such unambiguous interpretation of actions of «protectionist» groups overestimates the importance of the above-mentioned methods of influencing on power and, conversely, underestimates the role of compromise and forms of interests negotiation, which are targeted on the cooperation with the authority. We can agree that it is more correct to use this term for those groups and organizations that reach their goals relying mainly on their own strength and on the dependence of the authority on this force. Moreover, the main thing here is not the methods, not the demonstration of brute force, but the ability to achieve their goals. Pressure by itself can be very «delicate» and even invisible to the third-party eye [3].

From the point of view of pluralism, society consists of a large number of interest groups and pressure groups that represent all significant interests of the population and compete for each other for 52 their influence on state power. This competition takes place within the framework of the crosssectoral partnership, this means that the consensus is reached on the basic foundations of the economic and political system and the permissible level of conflict. Competition between groups and sectors of society ensures such a situation in which none of the groups is dominating and the balance of interests is maintained. This balance plays a crucial role for the stability of the existing social system.

Thus, the pluralistic concept of mediation understands the process of state functioning as the pressure of various interest groups and, accordingly, the division of power in society. Therefore, pluralism can be defined as a system of representation of interests in which its constituent elements are arranged in an unspecified number of complex, voluntary, competitive, non-hierarchical and self-defined (both about the type and scope of interest) entities that are not licensed specifically, not recognized, not subsidized or otherwise controlled (in relation to the choice of leadership or expression of interest) by the state and do not seek a monopoly of representative activity among the similar entities.

With this approach the public governance of the society is the proper allocation of scarce resources by the government under the pressure of interest groups that are active actors in the political process, while the state, represented by the government, plays a response function to the activities of interest groups. In other words it may be noted that the pluralistic approach is limited by the fact that it focuses more on the government rather than on the state as a whole. It does not take into account such a very important fact that the participants of the political activity on the part of the state have their own interests, which are included into the process of policy formation. Consequently, the pluralistic approach does not allow investigating fully politics as a system of interconnected relations between the state and society in which the state is not simply an agent of the response to the challenges of the pressure groups but is an active participant in the cooperation process.

It should be noted also that one of the most important features of pluralism is the large number of actors, which are involved in the political process. The pluralistic distribution of resources has more spontaneous character, which is close to the market competition. Redistribution of wealth and privilege is the effect of the organized pressure and the political decision-making is a result of intense competition, 
not the cooperation between interest groups as small interest groups. Such groups are relatively rarely guided by values, which are connected with the public interest, focusing mainly on receiving benefits. By our opinion, the most successful analysis of the interaction between government and business is the concept of «corporateism». It solves the problem of the relationship between the public interests and the state structures by its own way as it arose partly as a critical response to the disadvantages of the pluralist approach to the mediation of interests. Contrary to pluralism, corporatism considers the state to be one of the most important institutional element of relations between the groups of interests and power. In its classical definition, suggested by F. Schmitter in 1974, the modern corporatism is defined as a «system of representation of interests during which constituent parts are organized into several special, compulsory, non-competitive, hierarchically ordered, functionally different levels, are recognized or permitted officially (or even simply created) by the state that gives them a monopoly of presentation in their sphere in exchange for a certain control over the selection of leaders and articulation of requirements and attachments «[4, c. 15].

The authoritarian and liberal corporatism can be distinguished. The liberal one is a special type of participation of large organized groups in the development of public policy, mainly in the field of economics, which is characterized by a high level of inter-group cooperation. Liberal corporatism does not apply for substituting the institutional mechanisms of parliamentary and party management, but at the same time it promotes greater integration of the state system. It can not be identified only with consultations and cooperation between the government and the interest groups. The essential characteristics of the liberal corporatism are the high level of institutional integration of conflicting groups and the high degree of cooperation between groups in the development of the state policy. Proponents of the concept of liberal corporatism believe that interest groups act in conditions of democracy along with the articulation of interests and «pressure» on power, an extremely important function of control over the activities of the state administration (whose units themselves are groups of interests).

\section{Conclusions.}

Assessing the theoretical approaches to the study of business as a political actor, it is necessary to pay attention to the fact that all these approaches are linked very closely with the general ideological setting of one or another author. Despite the declared desire for the scientific objectivity, the adherence to one or another political outlook can not but influence the position of a particular researcher, especially on such politically acute issue, which a question of the relationship between the business and government in Ukraine is today.

From the concepts discussed in the article and analysis of the interaction between government and business, the corporatism approach can be considered to be the most appropriate for Ukrainian realities. The understanding of the state as a separate corporation, which has its own, distinct from the business structures interests and at the same time which builds partnership relations with them provides opportunities for the more detailed analysis of the organizational forms of interaction of power and business, the peculiarities of public administration in this sphere, and in addition is taking into account the trends of globalization, which impose restrictions on this interaction.

\section{REFERENCES}

1. Achkasov, V.A. (2002). Sravnitelnaya politologiya [Comparative politics]. Saint Petersburg: SPbGU [in Russian].

2. Burlatskiy, F.M., \& Galkin, A.A. (1985). Sovremennyy Leviafan: Ocherki politicheskoy sotsiologii kapitalizma [Modern Leviathan: Essays on the political sociology of capitalism]. Moscow: Mysl [in Russian]. 3. Peregudov, S.P., Lapina, N.Yu., \& Semenenko, I.S. (1999). Gruppy interesov i Rossiyskoe gosudarstvo [Interest groups and the Russian state]. Moscow: Editorial URSS [in Russian].

4. Shmitter, F. (1997). Neokorporatizm [Neocorporatism]. Politicheskie issledovaniya, 2, 14-22 [in Russian]. 5. Burlatskiy, F.M., \& Chirkin, V.Ye. (Eds.). (1976). Politicheskie sistemy sovremennosti: Ocherki [Modern Political systems: essays]. Moscow: Nauka [in Russian].

6. Offe, C., \& Ronge, V. (1982). Theses on the Theory of the State. Classes, power and conflict: Classical and contemporary debates. A. Ciddens, D. Held (Eds.). Berkeley: Los Angeles Univ. of California Press. 
7. Poulantzas, N. (1973). The Problem of the Capitalist State. Ideology in Social Science: Readings in critical social theory. R. Blackburn (Eds.). London: Collins.

8. Richardson, J. (Eds.). (1994). Pressure Groups. Oxford: Oxford University Press.

9. Truman, D. (1971). The Governmental Process. Political Interests and Public Opinion. New York: Knopf.

\section{Квітка Сергій Андрійович}

Кандидат філософських наук, доцент

Дніпропетровський регіональний інститут державного управління Національної академії державного управління при Президентові України

49044, Дніпро, вул. Гоголя, 29

\section{Kvitka Sergiy A.}

As. Prof., Ph. D.

Dnipropetrovsk regional institute of public administration of National academy for public

administration under the President of Ukraine

29, Gogol Str., Dnipro, 49044, Ukraine

ORCID 0000-0003-3786-9589_Ｅmail:skvitka@i.ua

Цитування: Квітка С. А. Державне управління взаємодією влади та бізнесу: європейський досвід для України / С. А. Квітка // Аспекти публічного управління. - 2018. - Т. 6. - № 4. - С. 48-54.

Citation: Kvitka, S.A. (2018). Public administration of the interaction between government and business: European experience for Ukraine. Public administration aspects, 6 (4), 48-54. 